\title{
The effects of ozone on the acute phase of intestinal ischemia-reperfusion injury in rats
}

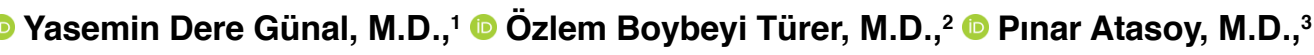 \\ (D) Üçler Kısa, M.D., ${ }^{4}$ @ Mustafa Kemal Aslan, M.D. ${ }^{1}$
}

\author{
${ }^{1}$ Department of Pediatric Surgery, Kırıkkale University Faculty of Medicine, Kırıkkale-Turkey \\ ${ }^{2}$ Department of Pediatric Surgery, Hacettepe University Faculty of Medicine, Ankara-Turkey \\ ${ }^{3}$ Department of Pathology, Kırıkkale University Faculty of Medicine, Kırıkkale-Turkey \\ ${ }^{4}$ Department of Biochemistry, Kırıkkale University Faculty of Medicine, Kırıkkale-Turkey
}

\begin{abstract}
BACKGROUND: In this study, we aimed to examine the therapeutic effects of ozone on the acute phase of intestinal ischemia-reperfusion (I/R) injury in rats to resemble clinical practice.

METHODS: Eighteen Wistar albino rats were assigned to control (CG, $n=6$ ), sham (SG, $n=6$ ) and ozone groups (OG, $n=6)$. A midline laparotomy was performed and a superior mesenteric artery (SMA) in the SG and OG was occluded with a 0/0 catgut suture, but in the CG, the incision was closed without any intervention. Tissue oxygenation was monitored with a tissue oxygenation monitor to achieve the same grade during intestinal ischemia. The incision was closed and, in the OG, ozone/oxygen mixture $(0.7 \mathrm{mg} / \mathrm{kg}) \mathrm{was}$ injected intraperitoneally, 20 minutes before reperfusion. Surgical incision was reopened and reperfusion was achieved after 60 minutes of ischemia in the SG and OG. After 60 minutes of reperfusion, $2 \mathrm{~cm}$ small intestine segment was sampled for histopathological assessment of the intestinal mucosal damage (Chiu score) and biochemical assessment of oxidative stress markers (nitric oxide: NO, malondialdehyde: MDA, superoxide dismutase: SOD) in all groups.
\end{abstract}

RESULTS: The Chiu scores of the SG and OG were statistically increased than that of the CG ( $p=0.002$; and $p=0.002$, respectively). Chiu score in the OG was higher compared to that in the SG, but not statistically significant $(p=0.175)$. MDA levels were statistically higher in the SG and OG than that of the CG ( $p=0.004$; and $p=0.010$, respectively). However, the difference between the SG and OG was not statistically significant $(p=0.522)$. SOD and NO levels were not significantly different between groups $(p=0.45 \mathrm{I}$ and $p=0.056$, respectively).

CONCLUSION: Contrary to the literature, single-dose ozone therapy did not reduce the oxidative stress or improve the ischemic damage in intestinal I/R injury in rats. Further evaluation with different doses in different time periods is needed for potential clinical use.

Keywords: Experimental; Intestine; ischemia/reperfusion injury; ozone.

\section{INTRODUCTION}

Intestinal I/R injury is an urgent and severe condition with high morbidity and mortality rates because it results in multiple organ failure, intestinal atrophy, sepsis and vascular protein and fluid leakage..$^{[1,2]}$ The common clinical causes of intestinal I/R injury include necrotizing enterocolitis in newborns, malrotation and volvulus, intussusception, septic shock, incarcerated inguinal hernia, trauma, mesenteric artery embo- lism, and severe burns in children. ${ }^{[3-6]}$ It has been shown that the end products of anaerobic metabolism and accumulation of toxic products due to the inadequate distribution of blood flow and oxygen lead to primary ischemic damage. ${ }^{[1,2,5]}$ Furthermore, the reactive oxygen free radicals cause damage to the tissue directly or the cellular antioxidant systems in reperfusion injury. ${ }^{[1,3,5]}$ Although most of the recent studies on the treatment of $I / R$ injury are intended to prevent the tissues from the destructive effects of this reperfusion injury,

Cite this article as: Dere Günal Y, Boybeyi Türer Ö, Atasoy P, Kısa Ü, Aslan MK. The effects of ozone on the acute phase of intestinal ischemiareperfusion injury in rats. Ulus Travma Acil Cerrahi Derg 2020;26:651-656.

Address for correspondence: Yasemin Dere Günal, M.D.

Kırıkkale Üniversitesi Tıp Fakültesi, Çocuk Cerrahisi Anabilim Dalı, Kırıkkale, Turkey

Tel: +90 318 - 4444071 E-mail: drderegunal@yahoo.com

Ulus Travma Acil Cerrahi Derg 2020;26(5):65I-656 DOI: 10.14744/tjtes.2020.48672 Submitted: 06.08.2020 Accepted: 25.08.2020 Online: 09.09.2020

Copyright 2020 Turkish Association of Trauma and Emergency Surgery 
no effective therapeutic regimen has yet been described in the medical literature..$^{[2,4,6-8]}$

Ozone (O3) is a colorless gas having a characteristic odor at room temperature, consisting of three oxygen atoms. Ozone has adverse effects on the human body, such as damage to cells and tissues, because of its strong oxidation activity, especially at high concentrations. ${ }^{[9-11]}$ However, ozone can act as an antioxidant agent at low doses, decreasing tissue oxidative stress parameters, such as lipid peroxidation, protein oxidation, and nitrite/nitrate, and increasing the activity of enzymes, which are cellular antioxidants, such as catalase and glutathione peroxidase. Furthermore, it may also affect the production and release of proinflammatory cytokines from inflammatory cells and activate the immune and neuroendocrine systems by increasing the blood circulation and oxygen delivery at low doses. ${ }^{[2,6-8,12-15]}$ Due to these antioxidant and anti-ischemic effects, clinical studies have suggested that ozone therapy is useful to treat many diseases, including peritonitis, wound infections, burns, skin ulcers, and gangrene. ${ }^{[6,7]}$ However, there are few experimental studies regarding the effects of ozone on intestinal I/R injury and also there is a lack of standardization among them.

We conducted this study to experimentally investigate the effects of ozone in the acute stage of an intestinal I/R injury model in rats by trying to simulate the clinical scenario.

\section{MATERIALS AND METHODS}

This experimental study was carried out according to the guides of the laboratory animals in the studies determined by the Local Ethical Committee (Approval Number: 46I3-00I4).

Eighteen Wistar albino male adult rats were used, which weighed $250 \pm 50 \mathrm{~g}$ in this study. The rats were fed with tap water and ad libitum food in a $12 \mathrm{~h}$ day/night cycle at $22^{\circ} \mathrm{C}$. The rats were randomly assigned to three groups as follows:

- Control group (CG, n=6): Laparotomy was performed, but intestinal I/R injury was not developed and no chemical was administered.

- Sham group (SG, n=6): Laparotomy and intestinal I/R injury were performed.

- Ozone group (OG, n=6): Laparotomy, intestinal I/R injury, and intraperitoneal $95 \%$ oxygen plus $5 \%$ ozone gas mixture $(0.7 \mathrm{mg} / \mathrm{kg})$ (Evozone Basic Plus, Germany) infusion $20 \mathrm{~min}-$ utes before the reperfusion was performed.

\section{Surgical Procedures}

The rats were anesthetized with an intraperitoneal injection of

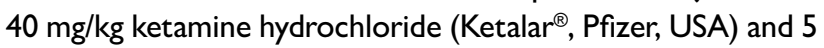
$\mathrm{mg} / \mathrm{kg}$ xylazine hydrochloride (Rompun ${ }^{\circledR} 2 \%$, Bayer, Germany).

All animals were fixed in the supine position on the operating table after applying a sedation anesthesia, and abdominal lapa- rotomy was performed under sterile conditions, following the interference with a midline incision. Afterwards, the SMA in the SG and OG was exposed and occluded with a $0 / 0$ catgut suture as described previously, ${ }^{[4]}$ but in the $\mathrm{CG}$, the incision was closed without any intervention. In the SG and OG, the tissue oxygenation monitor (MoorVMS-OXY, Moor Instruments, UK) was used to achieve the same grade of intestinal ischemia (Fig. I). Tissue oxygenation was monitored during intestinal ischemia and was expressed as percentages. It was also observed macroscopically that the pulsation of the SMA stopped, and the color of the small intestine became purple. We appropriately closed the surgical incision layers after SMA occlusion. In the $O G$, the ozone/oxygen mixture $(0.7 \mathrm{mg} / \mathrm{kg})^{[16]}$ was injected intraperitoneally, 20 minutes before reperfusion. Surgical incision was reopened and reperfusion was achieved by opening the catgut knots on the SMA carefully, after 60 minutes of intestinal ischemia in the SG and OG. Then, the incision was closed again. After 60 minutes of the reperfusion period, ischemic small intestine segment measuring $2 \mathrm{~cm}$ ( $15 \mathrm{~cm}$ closer to the ileocecal valve) of each rat was sampled for histopathological examination of the mucosal damage (Chiu score) ${ }^{[17]}$ and biochemical investigation of markers of oxidative stress (nitric oxide: NO, malondialdehyde: MDA, superoxide dismutase: SOD). The half part of the intestine was kept in $10 \%$ buffered formaldehyde at room temperature for histopathological analysis, and the remaining part was kept at $-80^{\circ} \mathrm{C}$ in dry air for biochemical analysis. The rats were sacrificed by exsanguination.

\section{Histopathological Analyses}

Routine light microscopic tissue examination was applied to all the tissue samples. Serial sections ( $5 \mu \mathrm{m}$ thick) were stained with haematoxylin-eosin and analyzed by a light microscope (Leica ${ }^{\circledR}$ Microsystems, Wetzlar $\mathrm{GmbH}$ ). The sections were examined by an experienced pathologist who was blinded to the groups. For histopathological examination of the intestinal I/R injury, the grading system according to Chiu was applied to all samples (Table I). ${ }^{[1]}$
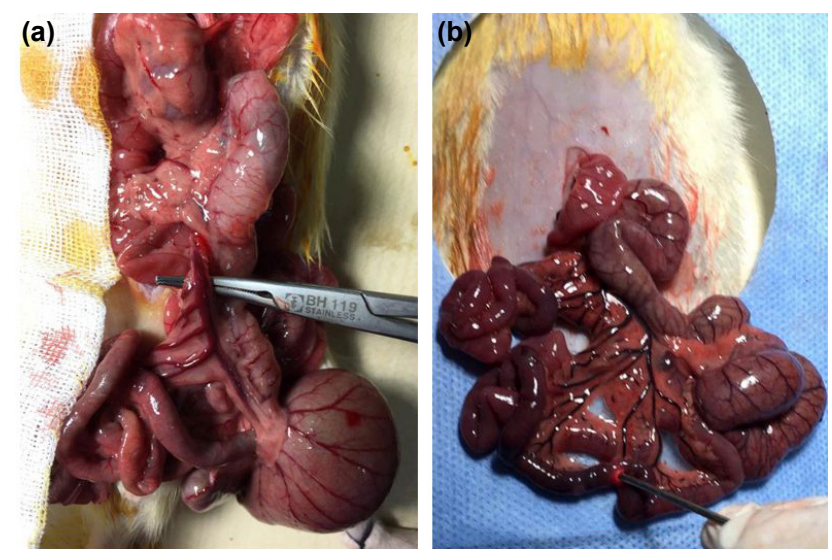

Figure 1. The experimental model. (a) The superior mesenteric artery is prepared for occlusion and. (b) The measurement of bowel perfusion using tissue oxygenation monitor. Note that the color of the small intestine became purple after the SMA was occluded. 
Table I. Histopathologic grades of colonic tissue (Chiu scoring system ${ }^{[17]}$ )

\begin{tabular}{|c|c|}
\hline Grade & Histopathologic finding \\
\hline 0 & Normal mucosal villi \\
\hline I & $\begin{array}{l}\text { Development of a subepithelial space, usually at the } \\
\text { tip of the villus, with capillary congestion }\end{array}$ \\
\hline II & $\begin{array}{l}\text { Extension of the subepithelial space with the } \\
\text { moderate lifting of the epithelial layer }\end{array}$ \\
\hline III & Massive epithelial lifting down the sides of villi \\
\hline IV & $\begin{array}{l}\text { Denuded villi with lamina propria, dilated capillaries } \\
\text { exposed, increased cellularity of the lamina propria }\end{array}$ \\
\hline V & $\begin{array}{l}\text { Digestion and disintegration of the lamina propria, } \\
\text { hemorrhage and ulceration }\end{array}$ \\
\hline
\end{tabular}

\section{Biochemical Analyses}

All samples were kept in dry air at $-80^{\circ} \mathrm{C}$. A homogenate was prepared for all tissues with saline solution in ice $(\mathrm{I} \mathrm{mL})$ and was then centrifuged at $1500 \mathrm{~g}$ for $10 \mathrm{~min}$ at $4{ }^{\circ} \mathrm{C}$. After centrifugation, MDA, NO, and SOD levels were determined in all the supernatants.

MDA levels, a standard curve of MDA (I,I,3,3-tetraethoxypropane) levels were defined using the method of Armstrong and al-Awadi. ${ }^{[18]}$ and results were given as $\mathrm{nmol} / \mathrm{mg}$ protein.

NO levels were measured using a spectrophotometric pro- cedure according to Miranda et al. ${ }^{[19]}$ The nitrate content was quantified by reducing nitrate with vanadium (III), using the Griess reaction to reflect the total nitrate and nitrite in the specimen. Serial dilutions of $\mathrm{Na}$ nitrate were made to achieve standard concentration. The results were given as $\mu \mathrm{mol} / \mathrm{g}$ protein.

SOD levels were quantified using an ELISA (Cayman Chemical Company, USA). The results were given as $U / \mathrm{mg}$ protein.

\section{Statistical Analysis}

Kruskal-I Wallis test was used for histopathological grades and MDA levels that did not show the normal distribution and inhomogeneous variations between the groups. The Mann-Whitney $U$ test was used for post hoc evaluation of differences between the groups.

One-Way ANOVA test was used for NO and SOD levels that were normally distributed and homogenous among the groups. Statistical significance was set at $p$-values lower than 0.05 .

\section{RESULTS}

Tissue oxygenation in the CG ranged from $94 \%$ to $98 \%$, while during intestinal ischemia, it ranged from $35 \%$ and $45 \%$ in the SG and OG measured using the tissue oxygenation monitor.

The results of the biochemical and histopathological examinations are presented in Table 2 and Figure 2. The harvested in-

Table 2. The median values of biochemical results

\begin{tabular}{lcccc}
\hline & $\begin{array}{c}\text { NO } \\
(\boldsymbol{\mu} \text { mol/g protein) }\end{array}$ & $\begin{array}{c}\text { MDA } \\
(\text { nmol/mg protein) }\end{array}$ & $\begin{array}{c}\text { SOD } \\
\text { (U/mg protein) }\end{array}$ & Chiu Scores \\
\hline Control group & $2.17(0.35-5.19)$ & $2.49(1.60-3.33)^{\alpha, \beta}$ & $4.25(3.82-4.56)$ & $0(0-0)^{\gamma, \theta}$ \\
Sham group & $2.71(0.12-6.93)$ & $6.40(2.81-19.12)^{\alpha}$ & $4.56(3.05-6.57)$ & $2(1-4)^{\gamma}$ \\
Ozone group & $3.78(1.80-4.82)$ & $6.43(3.55-13.81)^{\beta}$ & $3.33(2.65-3.98)$ & $4(1-5)^{\theta}$ \\
\hline
\end{tabular}

NO, MDA, SOD and Chiu scores of the groups (interquartile ranges within brackets). The statistically significant differences were indicated with small Greek letters ( $\alpha$, $\beta, \gamma, \theta: p<0.05)$. NO: Nitric oxide; MDA: Malondialdehyde; SOD: Superoxide dismutase.
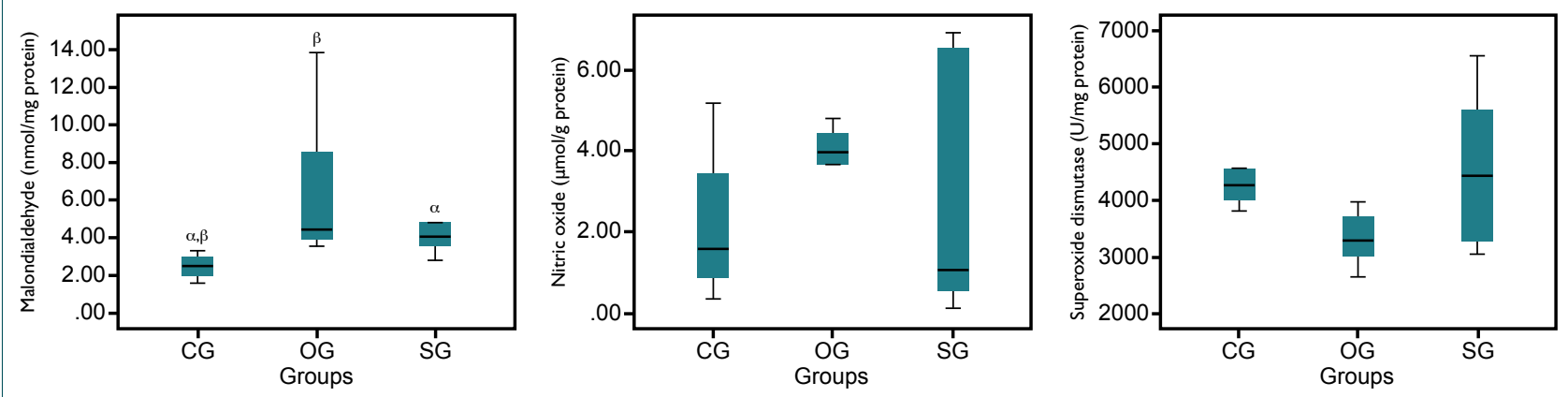

Figure 2. The median values of MDA, NO and SOD between the groups: $\alpha$ and $\beta$ represent the significant difference. NO: Nitric oxide; MDA: Malondialdehyde; SOD: Superoxide dismutase; CG: Control group, SG: Sham group, OG: Ozone group. 

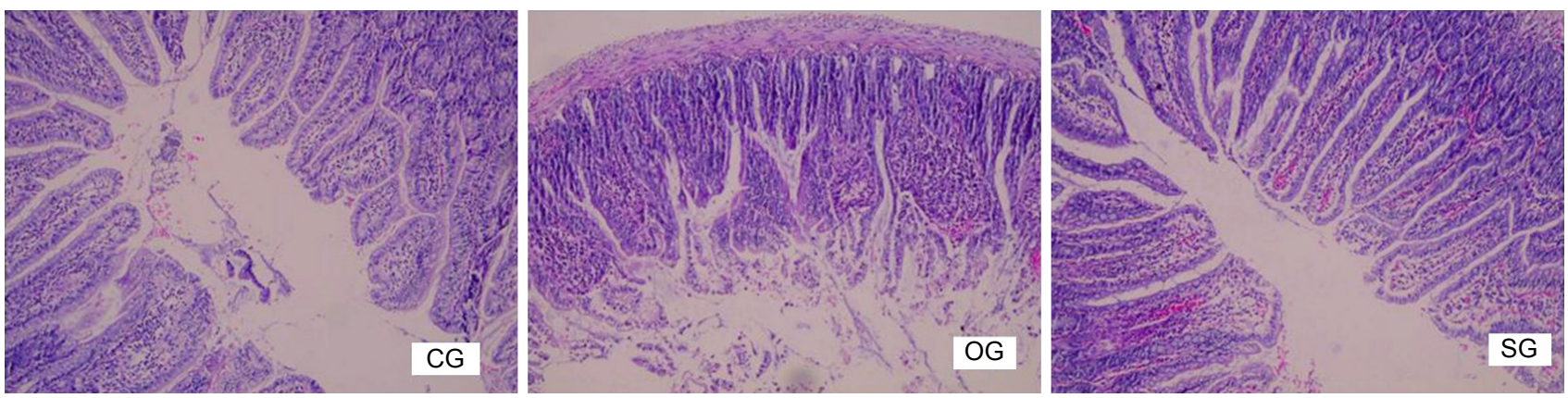

Figure 3. The light microscope findings of intestinal samples $(H \& E \times 100)$. CG: Normal findings. OG: Shedding at the ends of intestinal villi and increased mononuclear cell infiltration in the mucosa. Large epithelial lifting from the villi and cellular increase in the lamina propria. SG: Mucosal edema and capillary congestion with focal epithelial separations on the tips of the villi.

testines were observed macroscopically to be edematous and discolored. The specimens were graded using the Chiu score for the histopathological evaluation of intestinal injury (Table 2). The Chiu scores were compatible with the macroscopic appearance. A significant increase was found in the SG and $O G$ when the Chiu score was compared to the $C G(p=0.002$; and $p=0.002$, respectively). Although not significant, the Chiu score in the OG was higher compared to that of the SG $(p=0.175)$. Representative microscopic views of the groups are shown in Figure 3.

The median values of the MDA levels were statistically higher in the SG and OG than that of the CG $(p=0.004$; and $P=0.010$, respectively). However, the difference between the SG and OG was not statistically significant $(p=0.522)$. The median values of $N O$ were numerically higher in the $O G$ than the other groups, while the median values of SOD were numerically lower, but this was not statistically significant $(p=0.056$; and $p=0.45 \mathrm{I}$, respectively).

\section{DISCUSSION}

It has been demonstrated that cellular necrosis and apoptosis occurring in the ischemic environment produces proinflammatory substances from the polymorphonuclear cells, such as nitrogen- and oxygen-derived free radicals, prostaglandins, thromboxanes, prostacyclins, interleukins, tumor necrosis factor, and leukotrienes. These superoxide and hydroxyl radicals enter into the lipid peroxidation reaction that can destroy the cell membrane and its permeability. This cell membrane destruction particularly induces the development of cell death and the release of the free radicals, protease enzymes, and peroxides. These substances also increase further tissue damage. ${ }^{[1,2,6]}$ The published data reveal inconsistencies in the effects of ozone on apoptosis and cell death. Many studies have suggested that ozone stimulates cell death. [20] The way of cell damage due to ozone has not yet been fully understood. One study has suggested that ozone stimulates lipid peroxidation, causing oxidative stress and DNA injury. MDA is indicative of lipid peroxidation in tissues, and increased levels represent oxidative damage. ${ }^{[2]}$ In the present study, MDA levels of the ischemic rats (SG and OG) were significantly higher than the control rats (CG). However, the MDA levels of the OG were statistically similar to those of the SG, suggesting that ozone has no protective effect on lipid peroxidation in the cell membrane after intestinal $I / R$ injury in the rat. Borrego et al. ${ }^{[22]}$ demonstrated in a study regarding cisplatin-induced nephrotoxicity in rats that SOD and other antioxidants may decrease because of the increased $\mathrm{H}_{2} \mathrm{O} 2$, which could be increased by high dose ozone application. Furthermore, it has been shown in in vivo studies that high-dose ozone applied to the ischemic/hypoxic tissue could lead to decreased antioxidant enzyme levels. ${ }^{[2]}$ In the present study, the SOD levels of the OG were lower than the other groups numerically, but this was not statistically significant. The absence of a long-term I/R damage may have caused this result. Additionally, the degradation of antioxidant enzymes could increase if the ischemia and reperfusion time increases. ${ }^{[13]}$ It is reported that ozone seriously compromises cell membrane integrity and short-term repeated doses up-regulate cellular plasticity by inducing anti-apoptotic pathways. ${ }^{[23]}$

In the present study, histopathological examination revealed that the Chiu scores of the CG were significantly lower than the SG. Similar to our previous experience, these findings provide that the intestinal $I / R$ injury model applied in this study is successful and acceptable. ${ }^{[4]}$ Therefore, we can assume that occlusion of the SMA for an hour which provides intestinal tissue oxygenation of between $35 \%$ and $45 \%$, leads to significant $I / R$ damage in the intestine. Although a significant difference was not found, the median value of the Chiu score in the OG tended to increase compared to the SG. It can be concluded that a single-dose ozone therapy neither decreases the oxidative damage nor improves the evidence of the ischemic damage in intestinal I/R injury in rats, even though some worsening is observed.

Recently, ozone has been shown to have positive effects on antioxidant and histopathological parameters in intestinal I/R injuries with I mg/kg doses per day for five days, when given prophylactically before an ischemic injury was created in rats. ${ }^{\left[{ }^{6]}\right.}$ Given that it is very difficult to make a quick diagnosis of those patients within minutes, the preconditioning use of ozone will not be suitable for actual clinical practice, particu- 
larly in emergency cases. Since intestinal ischemia is usually an emergency condition, our aim was to assess the acute effects of single dose of the ozone. Thus, we designed our study with a delayed administration of ozone once the intestinal ischemia had occurred. Similarly, Haj et al. ${ }^{[7]}$ gave an equal mixture of ozone and oxygen in $0.7 \mathrm{mg} / \mathrm{kg}$ daily doses both intraperitoneally and intraluminally (50/50) for 72 hours after intestinal I/R injury in rats. They found successful results, including significantly increased intestinal villus height, decreased enterocyte apoptosis, and enhanced intestinal recovery. ${ }^{[7]}$ Isik et al. ${ }^{[2]}$ demonstrated that ozone has protective effects on mesenteric artery ischemia in rats if it is given intraperitoneally in $0.5 \mathrm{mg} / \mathrm{kg}$ single dose, 15 minutes after the ischemia. They stated that they would plan a prospective clinical study and use ozone therapy during the surgeries of real-time patients. [2] Contrary to these promising studies, our results did not show any therapeutic benefit of ozone but showed its oxidative effect. This may suggest that the therapeutic dose range of ozone is narrow.

Intraperitoneal administration of ozone is generally more efficient than oral administration. ${ }^{[2]}$ Since ozone is administered under ischemic conditions, the high oxygen pressure gradient will cause ozone to be transfused into the intestinal wall through passive diffusion. Therefore, ozone is effective in the entire ischemic intestine. ${ }^{[24]}$ In our study, the measured intestinal tissue oxygenation below $45 \%$ and the application of ozone in the late period of ischemia may cause the oxygen gradient in the intestine to increase further and more ozone to be transfused into the intestinal wall by passive diffusion. Consequently, this high dose ozone may have caused more damage to the intestinal wall. Given that it is unlikely to diagnose these patients at the 15 th minute of ischemia in clinical practice, ozone can worsen bowel damage in the late period of ischemia, when intestinal tissue perfusion remarkably decreases.

Previous studies provide evidence that ozone has protective effects on intestinal I/R damage. ${ }^{[2,6,7]}$ However, it should be noted that the amount of injury may vary depending on the compression pressure applied to the SMA and the duration of the ischemia. There are not enough data in the literature about the degree of intestinal ischemia developing after the SMA occlusion with any methods. It was decided that the SMA is occluded when the SMA pulsation stopped and the color of the intestine changed into the purple. Although the applied force is considered to be the same, the amount of tissue ischemia created may vary. Unlike the other studies mentioned above, a tissue oxygenation monitor was used to achieve similar to SMA compression in all subjects in this study. Although we could not physically measure the force applied to the SMA, we obtained the same tissue perfusion in all intestine using this device. Besides this, our results in contradiction with the literature may be related to the dose of ozone (in single or repetitive doses), the route of application and the time of administration. It is obvious that more studies are required to determine the appropriate dosage range and time of administration of ozone therapy to be used in clinical practice.

This study has some limitations. Since this study aimed to explore the possible useful effects of single-dose ozone in the acute stage of intestinal I/R injury, it did not involve the longterm effects of repeated doses of ozone therapy. Additionally, lack of ultrastructural changes associated with inflammatory response and apoptosis in the intestine after I/R and ozone therapy is a hindrance to have more precise conclusions. In this study, we used tissue oxygen level measurement only to standardize the ischemia level and did not compare this measurement with post-reperfusion. Considering that ozone therapy was ineffective in the acute stage of intestinal I/R injury, we think that the difference between tissue oxygenation did not affect the results between the groups. However, we believe that this study will inspire future research investigating tissue oxygenation changes, studying long-term ischemia-reperfusion models with different substances.

\section{Conclusion}

In conclusion, single-dose ozone therapy did not increase the antioxidant enzymes to reduce the oxidative stress and did not improve the evidence of the ischemic damage in intestinal $\mathrm{I} / \mathrm{R}$ injury in rats. Although ozone is reported to be an effective antioxidant in previous clinical and experimental studies, further evaluation with different doses in different time periods, including ischemic and/or reperfusion periods, is needed to be used for clinical purposes.

\section{Acknowledgment}

Authors thank to Bülent Bakar, M. D. Associate Professor from Kırıkkale University, Medical Faculty, Department of Neurosurgery, for the statistical analysis and evaluations of the results.

Ethics Committee Approval: Approved by the local ethics committee.

Peer-review: Internally peer-reviewed.

Authorship Contributions: Concept: Y.D.G.; Design: Y.D.G., Ö.B.T.; Supervision: Y.D.G., M.K.A.; Fundings: Y.D.G.; Materials: Y.D.G., Ö.B.T., P.A., Ü.K.; Data: Y.D.G., P.A., Ü.K.; Analysis: Y.D.G., Ö.B.T.; Literature search: Y.D.G.; Writing: Y.D.G.; Critical revision: Y.D.G., Ö.B.T., M.K.A.

Conflict of Interest: None declared.

Financial Disclosure: The authors declared that this study has received no financial support.

\section{REFERENCES}

1. Cerqueira NF, Hussni CA, Yoshida WB. Pathophysiology of mesenteric ischemia/reperfusion: a review. Acta Cir Bras 2005;20:336-43. [CrossRef]

2. Isik A, Peker K, Gursul C, Sayar I, Firat D, Yilmaz I, et al. The effect of ozone and naringin on intestinal ischemia/reperfusion injury in an exper- 
imental model. Int J Surg 2015;21:38-44. [CrossRef]

3. Vollmar B, Menger MD. Intestinal ischemia/reperfusion: microcirculatory pathology and functional consequences. Langenbecks Arch Surg 2011;396:13--29. [CrossRef]

4. Boybeyi O, Dere Gunal Y, Atasoy P, Kisa U, Aslan MK. The effect of colchicine and low-dose methotrexate on intestinal ischemia/reperfusion injury in an experimental model.J Pediatr Surg 2014;49:1471-4. [CrossRef]

5. Mallick IH, Yang W, Winslet MC, Seifalian AM. Ischemia-reperfusion injury of the intestine and protective strategies against injury. Dig Dis Sci 2004;49:1359-77. [CrossRef]

6. Onal O, Yetisir F, Sarer AE, Zeybek ND, Onal CO, Yurekli B, et al. Prophylactic Ozone Administration Reduces Intestinal Mucosa Injury Induced by Intestinal Ischemia-Reperfusion in the Rat. Mediators Inflamm 2015;2015:792016. [CrossRef]

7. Haj B, Sukhotnik I, Shaoul R, Pollak Y, Coran AG, Bitterman A, et al. Effect of ozone on intestinal recovery following intestinal ischemia-reperfusion injury in a rat. Pediatr Surg Int 2014;30:181-8. [CrossRef]

8. Oztosun M, Akgul EO, Cakir E, Cayci T, Uysal B, Ogur R, et al. The effects of medical ozone therapy on renal ischemia/reperfusion injury. Ren Fail 2012;34:921-5. [CrossRef]

9. Bocci V, Borrelli E, Travagli V, Zanardi I. The ozone paradox: ozone is a strong oxidant as well as a medical drug. Med Res Rev 2009;29:646-82.

10. Elvis AM, Ekta JS. Ozone therapy: A clinical review. J Nat Sci Biol Med 2011;2:66-70. [CrossRef]

11. Himuro H. The Effect of Ozone on Colonic Epithelial Cells. Kurume Med J 2018;64:75-81.

12. Fedakâr Senyücel M, Ayva ES, Aslan MK, Boybeyi O, Soyer T, Aksoy $\mathrm{N}$, et al. Comparison of the effect of contrast medium, air, and ozone on ischemia/reperfusion injury due to experimental intussusception model. Turk J Med Sci 2013;43:637-41. [CrossRef]

13. Aslan MK, Boybeyi Ö, Şenyücel MF, Ayva Ş, Kısa Ü, Aksoy N, et al. Protective effect of intraperitoneal ozone application in experimental ovarian ischemia/reperfusion injury. J Pediatr Surg 2012;47:1730-4. [CrossRef]

14. Rodríguez ZZ, Guanche D, Alvarez RG, Rosales FH, Alonso Y, Schulz S. Preconditioning with ozone/oxygen mixture induces reversion of some indicators of oxidative stress and prevents organic damage in rats with fecal peritonitis. Inflamm Res 2009;58:371-5. [CrossRef]

15. Koca K, Yurttaş Y, Yildız C, Caycı T, Uysal B, Korkmaz A. Effect of hyperbaric oxygen and ozone preconditioning on oxidative/nitrosative stress induced by tourniquet ischemia/reperfusion in rat skeletal muscle. Acta Orthop Traumatol Turc 2010;44:476-83. [CrossRef]

16. Guven A, Gundogdu G, Vurucu S, Uysal B, Oztas E, Ozturk H, et al. Medical ozone therapy reduces oxidative stress and intestinal damage in an experimental model of necrotizing enterocolitis in neonatal rats. J Pediatr Surg 2009;44:1730-5. [CrossRef]

17. Chiu CJ, McArdle AH, Brown R, Scott HJ, Gurd FN. Intestinal mucosal lesion in low-flow states. I. A morphological, hemodynamic, and metabolic reappraisal. Arch Surg 1970;101:478-83. [CrossRef]

18. Armstrong D, al-Awadi F. Lipid peroxidation and retinopathy in streptozotocin-induced diabetes. Free Radic Biol Med 1991;11:433-6. [CrossRef]

19. Miranda KM, Espey MG, Wink DA. A rapid, simple spectrophotometric method for simultaneous detection of nitrate and nitrite. Nitric Oxide 2001;5:62-71. [CrossRef]

20. Kosmider B, Loader JE, Murphy RC, Mason RJ. Apoptosis induced by ozone and oxysterols in human alveolar epithelial cells. Free Radic Biol Med 2010;48:1513-24. [CrossRef]

21. Pompella A. Biochemistry and histochemistry of oxidant stress and lipid peroxidation. Int J Vitam Nutr Res 1997;67:289-97.

22. Borrego A, Zamora ZB, González R, Romay C, Menéndez S, Hernán$\operatorname{dez} \mathrm{F}$, et al. Protection by ozone preconditioning is mediated by the antioxidant system in cisplatin-induced nephrotoxicity in rats. Mediators Inflamm 2004;13:13-9. [CrossRef]

23. Brink CB, Pretorius A, van Niekerk BP, Oliver DW, Venter DP. Studies on cellular resilience and adaptation following acute and repetitive exposure to ozone in cultured human epithelial (HeLa) cells. Redox Rep 2008;13:87-100. [CrossRef]

24. Gao C, Xu L, Chai W, Sun X, Zhang H, Zhang G. Amelioration of intestinal ischemia-reperfusion injury with intraluminal hyperoxygenated solution: studies on structural and functional changes of enterocyte mitochondria. J Surg Res 2005;129:298-305. [CrossRef]

\section{DENEYSEL ÇALIŞMA - ÖZET}

\section{Sıçanlarda ozonun bağırsak iskemi-reperfüzyon hasarının akut evresi üzerine etkisi Dr. Yasemin Dere Günal, ${ }^{1}$ Dr. Özlem Boybeyi Türer, ${ }^{2}$ Dr. Pınar Atasoy, ${ }^{3}$ Dr. Üçler Kısa, ${ }^{4}$ Dr. Mustafa Kemal Aslan ${ }^{1}$}

${ }^{1}$ Kırıkkale Üniversitesi Tıp Fakültesi, Çocuk Cerrahisi Anabilim Dalı, Kırıkkale ${ }^{2}$ Hacettepe Üniversitesi Tıp Fakültesi, Çocuk Cerrahisi Anabilim Dalı, Ankara ${ }^{3}$ Kırıkkale Üniversitesi Tıp Fakültesi, Patoloji Anabilim Dalı, Kırıkkale ${ }^{4}$ Kırıkkale Üniversitesi Tıp Fakültesi, Biyokimya Anabilim Dalı, Kırıkkale

AMAÇ: Klinik uygulamalara benzer şekilde sıçanlarda ozonun intestinal iskemi-reperfüzyon (I/R) hasarının akut fazı üzerindeki terapötik etkilerini incelemeyi amaçladık.

GEREÇ VE YÖNTEM: On sekiz Wistar albino sıçanı kontrol (CG, $n=6$ ), sham ( $S G, n=6$ ) ve ozon gruplarına (OG, $n=6$ ) ayrıldı. Laparatomiyi takiben SG ve OG'de süperiyor mezenterik arter (SMA) 0/0 katgut dikişle oklüde edildi, ancak CG'de herhangi bir girişim yapılmadan insizyon kapatıldı. Eşit derecede bağırsak iskemisi elde etmek için bir doku oksijenasyon monitörü kullanıldı. İnsizyon kapatıldı ve OG'de, reperfüzyondan 20 dakika önce ozon/oksijen karışımı $(0.7 \mathrm{mg} / \mathrm{kg})$ intraperitoneal olarak enjekte edildi. SG ve OG'de 60 dakikalık iskemi sonrası cerrahi insizyon tekrar açıldı ve reperfüzyon sağlandı. Atmış dakikalık reperfüzyondan sonra tüm gruplarda bağırsak mukozal hasarının (Chiu skoru) histopatolojik değerlendirmesi ve oksidatif stres belirteçlerinin (nitrik oksit: NO, malonildialdehit: MDA, süperoksit dismutaz: SOD) biyokimyasal değerlendirmesi için $2 \mathrm{~cm}$ 'lik ince bağırsak segmenti örneklendi.

BULGULAR: Chiu skorları SG ve OG'de CG'ye göre istatistiksel olarak yüksekti (sırasıyla, $p=0.002$ ve $p=0.002$ ). Chiu skoru OG'de SG'ye göre daha yüksekti, ancak istatistiksel olarak anlamlı değildi ( $p=0.175)$. MDA düzeyleri SG ve OG'de CG'ye göre istatistiksel olarak daha yüksekti (sırasıyla $p=0.004$ ve $p=0.010)$. Ancak, SG ve OG arasındaki fark istatistiksel olarak anlamlı değildi $(p=0.522)$. SOD ve NO düzeyleri açısından gruplar arasında anlamlı olarak fark yoktu (sırasıyla, $p=0.45$ I ve $p=0.056$ ).

TARTIŞMA: Literatürün aksine, tek doz ozon tedavisi, sıçanlarda bağırsak I/R hasarında oksidatif stresi azaltmadı ve iskemik hasarı iyileştirmedi. Potansiyel bir klinik kullanım için farklı zaman aralıklarında farklı dozları içeren daha ileri değerlendirmeler yapılması gerekmektedir. Anahtar sözcükler: Bağırsak; deneysel; iskemi/reperfüzyon hasarı; ozon. 